\title{
SYNTHESIS AND EVALUATION OF ANTI-INFLAMMATORY AND ANTIBACTERIAL ACTIVITIES OF SOME 1, 2-BENZISOXAZOLE DERIVATIVES
}

\author{
SARATH SASIKUMAR ${ }^{*}$, HARIPRIYA M. ${ }^{2}$, ANJALI T. ${ }^{3}$ \\ ${ }^{*}$ Dept. of Pharmaceutical Sciences, M. G University, Kottayam 686631, Kerala, India, ${ }^{2}$ College of Pharmaceutical Sciences Govt. Medical \\ College, Thiruvananthapuram 695011, Kerala, India, ${ }^{3}$ Nehru College of Pharmacy, KUHS University, Thrissur 680597, Kerala, India \\ Email: sarath.pharm@gmail.com
}

Received: 27 Jul 2016, Revised and Accepted: 06 Sep 2016

ABSTRACT

Objective: A series of 1,2-Benzisoxazole derivatives were synthesized and characterized by various analytical techniques like Melting point, Rf, FTIR, and NMR spectra.

Methods: Structures of the compounds were elucidated and evaluated for anti-inflammatory activity by HRBC membrane stabilization method, antibacterial activity against Escherichia coli and Staphylococcus aureus by cup plate method.

Results: The compounds 4a and 4e showed good anti-inflammatory activity compared with standard drug Diclofenac sodium and compounds $4 \mathrm{~b}$ and $4 \mathrm{~d}$ showed good antibacterial activity on compared with standard drug Gentamycin.

Conclusion: These compounds may serve as future leads for anti-inflammatory and antibacterial drug discovery.

Keywords: 1, 2-Benzisoxazole, Anti-inflammatory, Antibacterial activity

(C) 2016 The Authors. Published by Innovare Academic Sciences Pvt Ltd. This is an open access article under the CC BY license (http://creativecommons.org/licenses/by/4.0/) DOI: http://dx.doi.org/10.22159/ijcpr.2016v8i4.15281

\section{INTRODUCTION}

The nucleus selected for the present work is 1,2 benzisoxazole which is a versatile molecule. Benzisoxazole is an aromatic organic compound with a molecular formula $\mathrm{C}_{7} \mathrm{H}_{5} \mathrm{NO}$ containing a benzene fused isoxazole ring structure. Benzisoxazole has no household use. It is used primarily in industry and research. Being a heterocyclic compound, benzisoxazole finds use in research as a starting material for the synthesis of larger, usually bioactive structures. It is found within the chemical structures of pharmaceutical drugs such as the antipsychotic Risperidone [1] and the anticonvulsant Zonisamide [2-4]. Its aromaticity makes it relatively stable, although as a heterocycle, it has reactive sites which allow for functionalization. Molecules with substituted 1, 2-benzisoxazole often exhibit anti-inflammatory [5], analgesic, antifungal [6], antioxidant [5], analgesic [7], and antibacterial activity [8].

\section{MATERIALS AND METHODS}

All the chemicals and reagents used in the synthesis of titled compounds were of the analytical or synthetic grade. The melting points of synthesized compounds were determined by open capillary tube method, using liquid paraffin and are uncorrected. Infra-red spectra of the compounds were recorded using $\mathrm{KBr}$ pellets in the range of 4000-500 cm-1 on Jasco FTIR model 6200. ${ }^{1} \mathrm{H}$ NMR (300 MHz) spectra were recorded on Bruker Avance DPX 300 instruments using
DMSO as solvent and Tetramethyl silane (TMS) as an internal standard; Chemical shifts were recorded in parts per million (PPM). Analytical thin-layer chromatography (TLC) was performed on precoated TLC sheets of silica gel using toluene: chloroform: methanol (9: 3: 1) as mobile phase; Iodine vapour was used to identify the location of spots.

\section{Experimental section}

In the synthetic scheme, different aromatic aldehydes were treated with 0-hydroxy acetophenone in ethanol with a catalytic amount of $40 \% \mathrm{KOH}$, stirred and kept at RT for $24 \mathrm{hr}$, acidified with conc. $\mathrm{HCl}$ to form chalcones by Aldol condensation. It involves the acid-base reaction between a strong base (hydroxide ion) and a hydrogen located alpha to a carbonyl group and forms an enolate. The enolate attacks the carbonyl group of aromatic aldehyde without alpha hydrogens. The aldol undergoes an acid-base reaction with the remaining acidic $\alpha$-hydrogen is lost, followed by the loss of $\mathrm{OH}$-as a leaving group to give an enal. The net loss of $\mathrm{H}+$ and $\mathrm{OH}$-represents the loss of water. Various chalcones were treated with Hydroxylamine hydrochloride and potassium carbonate under reflux in ethanol; nucleophilic attach by the basic nitrogen compound (Hydroxylamine) on carbonyl carbon (Nucleophilic addition) to form Benzisoxazole derivatives [8].

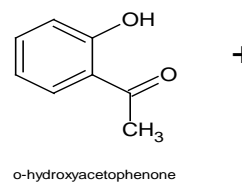

1

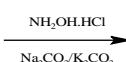<smiles>O=Cc1ccc(Br)cc1</smiles>

2<smiles>O=C(/C=C\c1ccccc1)c1ccccc1O</smiles>

3

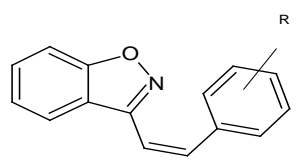

4

Fig. 1: Scheme for the synthesis of 1, 2-benzisoxazole derivatives 


\section{Synthesis of [3-[2-phenylethenyl]-1, 2-benzisoxazole] (4a)}

Step-1: A mixture of o-hydroxy acetophenone $(0.01 \mathrm{M})$ and Benzaldehyde (20\% 0.04 M) was dissolved in $10 \mathrm{ml}$ ethanol. To this mixture $10 \mathrm{ml}$ of $40 \% \mathrm{KOH}$ was added, the reaction mixture was stirred and kept at RT for $24 \mathrm{hr}$. Then the reaction mixture was poured over crushed ice and contents were acidified with concentrated hydrochloric acid. Chalcone thus obtained was purified by recrystallization from ethanol [8].

Step-2: A mixture of $2.77 \mathrm{gm}$ of chalcone $(10 \mathrm{mmol}), 0.7 \mathrm{gm}$ of Hydroxylamine hydrochloride $(10 \mathrm{mmol})$ and $1.4 \mathrm{gm}$ of anhydrous potassium carbonate $(10 \mathrm{mmol})$ in $50 \mathrm{ml}$ of ethanol was refluxed for $8 \mathrm{~h}$, then left to cool. The reaction mixture was poured into cold water, and the solid product was filtered off, washed with water, dried and finally crystallized from ethanol to afford Benzisoxazole derivative [8].

\section{Synthesis of [3-[2-(2-chlorophenyl) ethenyl]-1,2-benzisoxazole]} (4b)

Step-1: A mixture of o-hydroxy acetophenone $(0.01 \mathrm{M})$ and 2chlorobenzaldehyde $(20 \% 0.04 \mathrm{M})$ was dissolved in $10 \mathrm{ml}$ ethanol. To this mixture $10 \mathrm{ml}$ of $40 \% \mathrm{KOH}$ was added, the reaction mixture was stirred and kept at RT for $24 \mathrm{hr}$. Then the reaction mixture was poured over crushed ice and contents were acidified with concentrated hydrochloric acid. Chalcone thus obtained was purified by recrystallization from ethanol.

Step-2: A mixture of $2.77 \mathrm{gm}$ of chalcone $(10 \mathrm{mmol}), 0.7 \mathrm{gm}$ of Hydroxylamine hydrochloride $(10 \mathrm{mmol})$ and $1.4 \mathrm{gm}$ of anhydrous potassium carbonate $(10 \mathrm{mmol})$ in $50 \mathrm{ml}$ of ethanol was refluxed for 8 hours, then left to cool. The reaction mixture was poured into cold water, and the solid product was filtered off, washed with water, dried and finally crystallized from ethanol to afford Benzisoxazole derivative.

\section{Synthesis of [3-[2-(2, 4-dichlorophenyl) ethenyl]-1, 2 benz-} isoxazole] (4c)

Step-1: A mixture of o-hydroxy acetophenone (0.01 M) and 2,4dichlorobenzaldehyde $(20 \% 0.04 \mathrm{M})$ was dissolved in $10 \mathrm{ml}$ ethanol. To this mixture $10 \mathrm{ml}$ of $40 \% \mathrm{KOH}$ was added, the reaction mixture was stirred and kept at RT for $24 \mathrm{hr}$. Then the reaction mixture was poured over crushed ice and contents were acidified with concentrated hydrochloric acid. Chalcone thus obtained was purified by recrystallization from ethanol.
Step-2: A mixture of $2.77 \mathrm{gm}$ of chalcone (10 mmol), $0.7 \mathrm{gm}$ of Hydroxylamine hydrochloride $(10 \mathrm{mmol})$ and $1.4 \mathrm{gm}$ of anhydrous potassium carbonate $(10 \mathrm{mmol})$ in $50 \mathrm{ml}$ of ethanol was refluxed for $8 \mathrm{~h}$, then left to cool. The reaction mixture was poured into cold water and the solid product was filtered off, washed with water, dried and finally crystallized from ethanol to afford Benzisoxazole derivative.

Synthesis of [4-2-(1, 2-benzisoxazol-3-yl) ethenyl]-N, Ndimethylaniline] (4d)

Step-1: A mixture of o-hydroxy acetophenone $(0.01 \mathrm{M})$ and pdimethylamino benzaldehyde $(20 \% 0.04 \mathrm{M})$ was dissolved in $10 \mathrm{ml}$ ethanol. To this mixture $10 \mathrm{ml}$ of $40 \% \mathrm{KOH}$ was added, the reaction mixture was stirred and kept at RT for $24 \mathrm{hr}$. Then the reaction mixture was poured over crushed ice and contents were acidified with concentrated hydrochloric acid. Chalcone thus obtained was purified by recrystallization from ethanol.

Step-2: A mixture of $2.77 \mathrm{gm}$ of chalcone $(10 \mathrm{mmol}), 0.7 \mathrm{gm}$ of Hydroxylamine hydrochloride $(10 \mathrm{mmol})$ and $1.4 \mathrm{gm}$ of anhydrous potassium carbonate $(10 \mathrm{mmol})$ in $50 \mathrm{ml}$ of ethanol was refluxed for $8 \mathrm{~h}$, then left to cool. The reaction mixture was poured into cold water, and the solid product was filtered off, washed with water, dried and finally crystallized from ethanol to afford Benzisoxazole derivative.

Synthesis of [3-[2-(4-fluorophenyl) ethenyl]-1,2-benzisoxazole] (4e)

Step-1: A mixture of o-hydroxy acetophenone $(0.01 \mathrm{M})$ and 4flurobenzaldehyde $(20 \% 0.04 \mathrm{M})$ was dissolved in $10 \mathrm{ml}$ ethanol. To this mixture $10 \mathrm{ml}$ of $40 \% \mathrm{KOH}$ was added, the reaction mixture was stirred and kept at RT for $24 \mathrm{hr}$. Then the reaction mixture was poured over crushed ice and contents were acidified with concentrated hydrochloric acid. Chalcone thus obtained was purified by recrystallization from ethanol.

Step-2: A mixture of $2.77 \mathrm{gm}$ of chalcone $(10 \mathrm{mmol}), 0.7 \mathrm{gm}$ of Hydroxylamine hydrochloride $(10 \mathrm{mmol})$ and $1.4 \mathrm{gm}$ of anhydrous potassium carbonate $(10 \mathrm{mmol})$ in $50 \mathrm{ml}$ of ethanol was refluxed for $8 \mathrm{~h}$, then left to cool. The reaction mixture was poured into cold water, and the solid product was filtered off, washed with water, dried and finally crystallized from ethanol to afford Benzisoxazole derivative. The Physical characteristics of all the synthesized compounds are listed in table 1.

Table 1: Physical characterization data of all the synthesized compounds

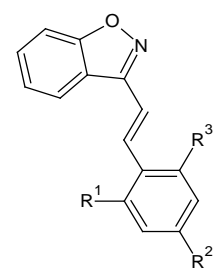

\begin{tabular}{|c|c|c|c|c|c|c|}
\hline Compound & $\mathbf{R}$ & Molecular formula & Molecular weight & Yield (\%) & m. p. $\left({ }^{\circ} \mathrm{C}\right)$ & ${ }^{*}$ Rf value \\
\hline $4 a$ & $\mathrm{R}^{1}-\mathrm{H}, \mathrm{R}^{2}-\mathrm{H}, \mathrm{R}^{3}-\mathrm{H}$ & $\mathrm{C}_{15} \mathrm{H}_{11} \mathrm{NO}$ & 221.259 & 45 & $110-114$ & 0.44 \\
\hline $4 \mathrm{~b}$ & $\mathrm{R}^{1}-\mathrm{Cl}, \mathrm{R}^{2}-\mathrm{H}, \mathrm{R}^{3}-\mathrm{H}$ & $\mathrm{C}_{15} \mathrm{H}_{10} \mathrm{ClNO}$ & 255.704 & 52 & $95-97$ & 0.55 \\
\hline $4 c$ & $\mathrm{R}^{1}-\mathrm{H}, \mathrm{R}^{2}-\mathrm{Cl}, \mathrm{R}^{3}-\mathrm{Cl}$ & $\mathrm{C}_{15} \mathrm{H}_{9} \mathrm{Cl}_{2} \mathrm{NO}$ & 290.149 & 58 & $78-80$ & 0.68 \\
\hline $4 d$ & $\mathrm{R}^{1}-\mathrm{H}, \mathrm{R}^{2}-\mathrm{N}\left(\mathrm{CH}_{3}\right)_{2}, \mathrm{R}^{3}-\mathrm{H}$ & $\mathrm{C}_{17} \mathrm{H}_{16} \mathrm{~N}_{2} \mathrm{O}$ & 264.328 & 55 & $92-95$ & 0.52 \\
\hline $4 \mathrm{e}$ & $\mathrm{R}^{1}-\mathrm{H}, \mathrm{R}^{2}-\mathrm{F}, \mathrm{R}^{3}-\mathrm{H}$ & $\mathrm{C}_{15} \mathrm{H}_{10} \mathrm{FNO}$ & 239.249 & 60 & $83-87$ & 0.62 \\
\hline
\end{tabular}

* Solvent system for TLC-toluene: chloroform: methanol (9:3:1)

\section{[3-[2-phenylethenyl]-1, 2-benzisoxazole] (4a)}

IR (KBr Vmax cm-1): Aromatic C-H str at $3253 \mathrm{~cm}^{-1}, \mathrm{C}=\mathrm{C}$ str at $1454 \mathrm{~cm}$ $1, \mathrm{C}=\mathrm{N}$ str at $1603 \mathrm{~cm}^{-1}, \mathrm{C}-0 \mathrm{str}$ at $1222 \mathrm{~cm}^{-1} .{ }^{1} \mathrm{HNMR}\left(\mathrm{CDCl}_{3}\right) \delta \mathrm{ppm}$ : 7.0-8.3 (Ar-H, 9H), 3.5-5.3 (olefinc-H, 2H), 1.5-2.9 (cyclic- $\mathrm{H}, 2 \mathrm{H}$ ).

\section{[3-[2-(2-chlorophenyl) ethenyl]-1,2-benzisoxazole] (4b)}

IR ( $\mathrm{KBr}$ Vmax cm-1): Aromatic C-H str at $3261 \mathrm{~cm}^{-1}, \mathrm{C}=\mathrm{C}$ str at 1482 $\mathrm{cm}^{-1}, \mathrm{C}=\mathrm{N}$ str at $1604 \mathrm{~cm}^{-1}, \mathrm{C}-\mathrm{O}$ str at $1225 \mathrm{~cm}^{-1}, \mathrm{C}-\mathrm{Cl}$ str at $754 \mathrm{~cm}^{-1}$.
${ }^{1} \mathrm{HNMR}\left(\mathrm{CDCl}_{3}\right) \delta$ ppm: 7.0-8.4 (Ar-H, 8H), 3.8-5.6 (olefinc-H, 2H), 1.6-2.7 (cyclic-H, 2H).

\section{[3-[2-(2, 4-dichlorophenyl) ethenyl]-1, 2 benzisoxazole] (4c)}

IR (KBr Vmax cm-1): Aromatic C-H str at $3270 \mathrm{~cm}^{-1}, \mathrm{C}=\mathrm{C}$ str at 1526 $\mathrm{cm}^{-1}, \mathrm{C}=\mathrm{N}$ str at $1609 \mathrm{~cm}^{-1}, \mathrm{C}-0$ str at $1225 \mathrm{~cm}^{-1}, \mathrm{C}-\mathrm{Cl}$ str at $737 \mathrm{~cm}^{-}$ ${ }^{1} .{ }^{1} \mathrm{HNMR}\left(\mathrm{CDCl}_{3}\right) \delta \mathrm{ppm}: 7.0-8.4(\mathrm{Ar}-\mathrm{H}, 7 \mathrm{H}), 3.8-5.6$ (olefinc- $\mathrm{H}, 2 \mathrm{H}$ ), 1.6-2.7 (cyclic- $\mathrm{H}, 2 \mathrm{H}$ ). 


\section{[4-2-(1, 2-benzisoxazol-3-yl) ethenyl]-N, N-dimethylaniline] (4d)}

IR (KBr Vmax cm-1): Aromatic C-H str at $3254 \mathrm{~cm}^{-1}, \mathrm{C}=\mathrm{C}$ str at 1482 $\mathrm{cm}^{-1}, \mathrm{C}=\mathrm{N}$ str at $1603 \mathrm{~cm}^{-1}, \mathrm{C}-0$ str at $1222 \mathrm{~cm}^{-1}, \mathrm{C}-\mathrm{N}$ str at $1328 \mathrm{C}-\mathrm{H}$ str (in $\mathrm{CH}_{3}$ ) at $2905 \mathrm{~cm}^{-1} .{ }^{1} \mathrm{HNMR}\left(\mathrm{CDCl}_{3}\right) \delta \mathrm{ppm}: 7.0-8.2(\mathrm{Ar}-\mathrm{H}, 8 \mathrm{H})$, 3.8-5.6 (olefinc- $\mathrm{H}, 2 \mathrm{H}$ ), 1.6-2.7 (cyclic- $\mathrm{H}, 2 \mathrm{H}$ ).

\section{[3-[2-(4-fluorophenyl)ethenyl]-1,2-benzisoxazole] (4e)}

IR ( $\mathrm{KBr}$ Vmax cm $\mathrm{cm}^{-1}$ ): Aromatic C-H str at $3225 \mathrm{~cm}^{-1}, \mathrm{C}=\mathrm{C}$ str at 1482 $\mathrm{cm}^{-1}, \mathrm{C}=\mathrm{N}$ str at $1604 \mathrm{~cm}^{-1}, \mathrm{C}-0$ str at $1225 \mathrm{~cm}^{-1}, \mathrm{C}-\mathrm{F}$ str at $1324 \mathrm{~cm}^{-1}$. ${ }^{1} \mathrm{HNMR}\left(\mathrm{CDCl}_{3}\right) \delta \mathrm{ppm}:$ 7.0-8.3 $(\mathrm{Ar}-\mathrm{H}, 8 \mathrm{H}), 3.8-5.6$ (olefinc- $\mathrm{H}, 2 \mathrm{H}$ ), 1.6-2.7 (cyclic-H, 2H).

\section{In vitro anti-inflammatory activity $[9,10]$}

Anti-inflammatory activities of the synthesized analogs were carried out by using Human Red Blood Cell (HRBC) membrane stabilization method at doses of $100 \mu \mathrm{gm}, 250 \mu \mathrm{gm}$, and $500 \mu \mathrm{gm}$. To the control test tube added $1 \mathrm{ml}$ solvent, $2 \mathrm{ml}$ phosphate buffer, $1 \mathrm{ml}$ hyposaline and $0.5 \mathrm{ml}$ of HRBC suspension. To the test tube add $1 \mathrm{ml}$ of the test compound, $2 \mathrm{ml}$ of phosphate buffer, $1 \mathrm{ml}$ of hyposaline and $0.5 \mathrm{ml}$ of HRBC suspension. The assay mixture was incubated at $37{ }^{\circ} \mathrm{C}$ for $30 \mathrm{~min}$ and centrifuged at $3000 \mathrm{rpm}$. The hemoglobin content in the supernatant solution was estimated by measuring the absorbance at $500 \mathrm{~nm}$. Diclofenac sodium $(100 \mu \mathrm{gm} / \mathrm{ml})$ was used as the standard drug. The control group was given Dimethyl sulphoxide (DMSO). Percentage inhibition of hemolysis can be calculated by the following formula,
$\%$ Inhibition of haemolysis $=100\left(\mathrm{OD}_{1}-\mathrm{OD}_{2}\right) / \mathrm{OD}_{1}$ Where,

$\mathrm{OD}_{2}=$ optical density of sample

$\mathrm{OD}_{1}=$ optical density of control

The results were analyzed for statistical significance by one-way ANOVA followed by Dunnett's test and reported in table 2.

\section{Antibacterial activity [8]}

Antibacterial activity of the synthesized compounds was assessed by cup plate method. All the five synthesized analogs of Benzisoxazole were evaluated for in vitro antibacterial activity against Escherichia coli (Gram-ve) and Staphylococcus auerus (Gram+ve). Nutrient agar (Hi-media) was used for culturing the bacteria. The sample solutions were prepared in chloroform. The concentrations used for antibacterial screening were $100,250,500 \mu \mathrm{g} / \mathrm{ml}$. Standard drug solution of Gentamicin $(100 \mu \mathrm{g} / \mathrm{ml})$ was prepared in distilled water Using a sterile cork borer of about $5 \mathrm{~mm}$ diameters, 5 wells were made in each Petri dish. Numbers were marked on the bottom of Petri dish to identify each cup. The sample solutions, standard solution and the vehicle control (chloroform) were placed in each cup of each Petri dish and incubated at $37 \pm 0.5{ }^{\circ} \mathrm{C}$ for $24 \mathrm{~h}$. The presence of a definite zone of inhibition of any size observed and compared with standard drug and is given in table 3.

Table 2: In vitro anti-inflammatory activity of synthesized analogues*

\begin{tabular}{|c|c|c|c|}
\hline Compound & Concentration $(\mu \mathrm{g} / \mathrm{ml})$ & Mean absorbance & \% inhibition \\
\hline Control & - & $1.710+0.0351$ & - \\
\hline Diclofenac sodium & 100 & $0.655+0.0130$ & 61.11 \\
\hline \multirow[t]{4}{*}{$4 a$} & 100 & $0.717+0.0209$ & 58.07 \\
\hline & 250 & $0.462+0.0141$ & 72.98 \\
\hline & 500 & $0.228+0.0102$ & 86.66 \\
\hline & 100 & $0.743+0.0321$ & 56.54 \\
\hline \multirow[t]{3}{*}{$4 b$} & 250 & $0.642+0.0127$ & 62.45 \\
\hline & 500 & $0.335+0.0133$ & 80.40 \\
\hline & 100 & $0.841+0.0382$ & 50.81 \\
\hline \multirow[t]{3}{*}{$4 c$} & 250 & $0.657+0.0126$ & 61.57 \\
\hline & 500 & $0.361+0.0140$ & 78.88 \\
\hline & 100 & $0.821+0.0367$ & 51.98 \\
\hline \multirow[t]{3}{*}{$4 d$} & 250 & $0.524+0.0198$ & 69.35 \\
\hline & 500 & $0.301+0.0138$ & 82.39 \\
\hline & 100 & $0.721+0.0212$ & 58.61 \\
\hline \multirow[t]{2}{*}{$4 \mathrm{e}$} & 250 & $0.462+0.0141$ & 72.98 \\
\hline & 500 & $0.276+0.0101$ & 83.85 \\
\hline
\end{tabular}

*Data expressed as mean \pm SEM. $(\mathrm{n}=4)$ and results considered significant when $\mathrm{P}<0.01$.

Table 3: Antibacterial activities of synthesized analogs

\begin{tabular}{|c|c|c|c|}
\hline \multirow[t]{2}{*}{ Compound } & \multirow[t]{2}{*}{ Concentrations $(\mu \mathrm{g} / \mathrm{ml})$} & \multicolumn{2}{|c|}{ Zone of inhibition (mm) } \\
\hline & & S. aureus & E. coli \\
\hline \multirow[t]{3}{*}{$4^{\circ}$} & 100 & 10 & 8 \\
\hline & 250 & 12 & 10 \\
\hline & 500 & 13 & 12 \\
\hline \multirow[t]{3}{*}{$4 b$} & 100 & 12 & 10 \\
\hline & 250 & 14 & 12 \\
\hline & 500 & 15 & 14 \\
\hline \multirow[t]{3}{*}{$4 c$} & 100 & 8 & 7 \\
\hline & 250 & 10 & 9 \\
\hline & 500 & 12 & 10 \\
\hline \multirow[t]{3}{*}{$4 d$} & 100 & 12 & 12 \\
\hline & 250 & 13 & 14 \\
\hline & 500 & 15 & 15 \\
\hline \multirow[t]{3}{*}{$4 \mathrm{e}$} & 100 & 12 & 8 \\
\hline & 250 & 14 & 9 \\
\hline & 500 & 15 & 10 \\
\hline Gentamycin & 100 & 16 & 16 \\
\hline Control & - & - & - \\
\hline
\end{tabular}




\section{RESULTS AND DISCUSSION}

The 1,2 Benzisoxazole analogs were synthesized using conventional synthetic methods, further recrystallized using ethanol and checked the purity by thin layer chromatography. Characterizations of the derivatives were carried out by melting point, Rf value, FTIR and ${ }^{1}$ HNMR.

FTIR spectra of all synthesized compounds show absorbance bands at range $3225-3270 \mathrm{~cm}^{-1}$ associated with Ar C-H str, bands at $1603-$ $1609 \mathrm{~cm}^{-1}$ for C-N str and bands at $1222-1225 \mathrm{~cm}^{-1}$ for C-O str. The ${ }^{1} \mathrm{HNMR}$ spectrum of synthesized compounds exhibit peaks in the range of 7.0-8.4 (Ar $\mathrm{H}$ ) and 3.5-5.6 (olefinic $\mathrm{H}$ ) of benzisoxazole.

The results of in vitro anti-inflammatory activity of test compounds given in table show that compounds $4 \mathrm{a}$ and $4 \mathrm{e}$ showed significant antiinflammatory activity similar to that of Standard drug Diclofenac sodium. The results of antibacterial activity of test compounds given in table shows that compounds $4 \mathrm{~b}$ and $4 \mathrm{~d}$ showed significant antibacterial activity against staphylococcus aureus and Escherichia coli.

\section{CONCLUSION}

A series of 1,2-Benzisoxazole derivatives were successfully synthesized and characterized. The compounds were further screened for in vitro anti-inflammatory and antibacterial activity. Compounds $4 \mathrm{a}$ and $4 \mathrm{e}$ showed significant anti-inflammatory activity similar to that of Standard drug Diclofenac sodium. Compounds $4 \mathrm{~b}$ and $4 \mathrm{~d}$ exhibited significant antibacterial activity against staphylococcus aureus, and Escherichia coli on compared with standard drug Gentamycin. The analogs can be subjected to further detailed studies for consideration as drug candidates.

\section{ACKNOWLEDGEMENT}

The authors are thankful to the faculties of the college of Pharmaceutical Sciences, Govt. Medical College, Thiruvananthapuram for their assistance.

\section{CONFLICT OF INTERESTS}

Declare none

\section{REFERENCES}

1. Robert L Findling, Michael G Aman, Marielle Eerdekens, Albert Derivan, Ben Lyons, Long-Term. Open-Label study of risperidone in children with severe disruptive behaviors and below-average IQ. Am J Psychiatry 2004;161:677-84.

2. Gaetano Zaccara, Luigi M Specchio. Long-term safety and effectiveness of zonisamide in the treatment of epilepsy: a review of the literature. Neuropsychiatr Dis Treat 2009;5:249-59.

3. Baulac M. The long-term retention of zonisamide in a large cohort of people with epilepsy at a tertiary referral center. Epilepsy Res 2006;2:S3-S9.

4. Veera Reddy Arava, Udaya Bhaskara Rao Siripalli, Vaishali Nadkarni, Rajendiran Chinnapillai. Novel base-catalyzed rearrangement of sultone oximes to 1, 2-benzisoxazole-3methane sulfonate derivatives. Beilstein J Org Chem 2007;3:20.

5. K Madhavi, K Bharathi, KVSRG Prasad. Synthesis and evaluation of 3-methyl-4-nitro-5-(substituted styryl) isoxazoles for antioxidant and anti-inflammatory activities. Res J Pharm Biol Chem Sci 2010;1:1073-82.

6. Ravindra M Kumbhare, VN Ingle. Synthesis of novel benzothiazole and benzisoxazole functionalized unsymmetrical alkanes and study of their antimicrobial activity. Indian J Chem 2009;48:996-1000.

7. Vijay kumar Tirlapur, Narasimha Gandhi, Raga Baswaraj, Rajendra Prasad Y. Synthesis, characterization and biological activities of some pyrimidines and isoxazoles bearing benzofuran moiety. Int J ChemTech Res 2010;2:1434-40.

8. RA Shastri, JS Varudkar. Synthesis and antimicrobial activity of 3-propene 1, 2-benzisoxazole derivatives. Indian J Chem 2009;48B:1156-60.

9. Varadarasou Mouttaya Mounnissamy, Subrahmanyan Kavimani, Vaithilingam Balu, Sabarimuthu Darlin Quine. Evaluation of anti-inflammatory and membrane stabilizing properties of ethanol extract of Cansjera rheedii J. Gmelin (Opiliaceae). Iranian J Pharmacol Ther 2007;6:235-7.

10. G Prakash Yoganandam, K Ilango, Sucharita De. Evaluation of anti-inflammatory an membrane stabilizing properties of various extracts of Punica granatum L (Lytheraceae). Int J PharmTech Res 2010;2:1260-3.

\section{How to cite this article}

- Sarath Sasikumar, Haripriya M, Anjali T. Synthesis and evaluation of anti-inflammatory and antibacterial activities of some 1, 2-benzisoxazole derivatives. Int J Curr Pharm Res 2016;8(4):64-67. 